\title{
Enhanced tolerance to bacterial pathogens caused by the transgenic expression of barley lipid transfer protein LTP2
}

\author{
A. Molina and F. García-Olmedo* \\ Laboratorio de Bioquímica y Biología Molecular, \\ Departamento de Biotecnología, E.T.S.I. Agrónomos- \\ UPM, E-28040 Madrid, Spain
}

\begin{abstract}
Summary
Purified lipid transfer protein LTP2 from barley applied on tobacco leaves eliminated symptoms caused by infiltration of Pseudomonas syringae pv. tabaci 153. Growth of the pathogen in leaves of transgenic tobacco plants was retarded when compared with non-transformed controls. The percentage of inoculation points that showed necrotic lesions was greatly reduced in transgenic tobacco (17$38 \%$ versus $78 \%$ ) and the average size of these lesions was $61-81 \%$ that of control. The average total lesion area (necrosis and chlorosis) in the transgenic plants was also reduced (38\% of control). Arabidopsis thaliana transgenic plants inoculated with P. syringse pv. tomato DC3000 also had lower percentages of necrotic lesions $122-38 \%$ versus $76 \%)$, a reduced average area for each lesion $(53-67 \%$ of control), and a smaller total lesion area per inoculation ( $43 \%$ of control). These results further support the assignment of a defense role for LTPs and highlight their biotechnological potential.
\end{abstract}

\section{Introduction}

It is generally assumed that a wide variety of proteins play different roles in the defense of plants against bacterial and fungal pathogens (Bowles, 1990). Thus, it has been proposed that some proteins enhance the strength of the extracellular matrix for passive resistance, others are enzymes involved in the biosynthesis of toxic compounds, such as phytoalexins, and a third group includes those that have direct anti-microbial activity. An increasing number of potential members of the latter group have been identified: thionins (Bohlman et al., 1988; Fernández de Caleya et al., 1972; Garcia-Olmedo et al., 1992; Molina et al., 1993a), glucanases and chitinases (Leah ot al., 1991; Mauch et al., 1988), ribosome-inactivating proteins (Leah et al., 1991), thaumatin-like proteins (Hejgaard et al,, 1991), zeamatins (Vigers et al., 1991), osmotins (Woloshuck et al., 1991), lipid transfer proteins (Garcia-Olmedo et al., 1995; Molina and García-Olmedo, 1991; Molina et al., 1993b; Segura et al., 1993; Terras et al., 1992a), defensins (Moreno et al.,
1994; Terras et al., 1992b), and others. However, the capacity to inhibit pathogens in vitro is not sufficient to postulate an in planta defense role for a particular protein, and additional criteria have been often used, such as the congruence of gene expression patterns with the proposed function, the in planta concentration and distribution of the protein before or after infection, and the potential to decrease symptoms in transgenic plants overexpressing the protein. The latter type of evidence, which is especially relevant, has been now provided for a number of proteins, including glucanases and chitinases (Broglie et al., 1991; Jach et al., 1995; Lin et al., 1995; Zhu et al., 1994), ribosomeinactivating proteins (Jach ot al., 1995; Logemman et al., 1992), thionins (Carmona et al., 1993), PR- Ta (Alexander et al., 1993), osmotin (Liu et al., 1994), and defensins (Terras et al., 1995).

Evidence supporting a defensive role for plant nonspecific lipid transfer proteins (LTPs) has recently been reviewed (García-Olmedo et al., 1995). These proteins were so named because of their ability to stimulate the transfer of a broad range of lipids between membranes in vitro (Arondel and Kader, 1990; Yamada, 1992). However, a cytoplasmic role is excluded for LTPs because they are generally secreted (Mundy and Rogers, 1986; Sterk et al., 1991) and externally associated with the cell wall (Molina and Garcia-Olmedo, 1991, 1993; Molina et al., 1993b; Pyee et al., 1994; Segura et al., 1993; Thoma et al., 1993). It has been speculated that they might be involved in the secretion or deposition of extracellular lipophilic materials, such as cutin or wax (Pyee et al., 1994; Sterk et al., 1991; Thoma et al., 1993; Hendriks et al, 1994). The in vitro antibiotic properties of LTPs against bacterial and fungal plant pathogens are now well established (Molina and Garcia-Olmedo, 1991; Molina et al., 1993b; Segura et al., 1993; Terras et at., 1992a) and their distribution at high concentrations over exposed surfaces and in the vascular tissue has been demonstrated (Fleming et al., 1992; Molina and Garcia-Olmedo 1993; Pyee et al., 1994; Thoma et al., 1993). Expression of Ltp genes has been shown to be induced well above basal levels in some plant-pathogen interactions, while in others the genes can be switched off by the pathogen (García-Olmedo et al., 1995; Molina and Garcia-Olmedo, 1993, 1994). We now present evidence that transgenic overexpression of the barley LTP2 protein under the control of a constitutive promoter in tobacco and Arabidopsis enhances tolerance to pathogens. This evidence further supports the assignment of a defensive role to LTPs and demonstrates their biotechnological potential in engineering plants that are resistant to pathogens. 
(a)

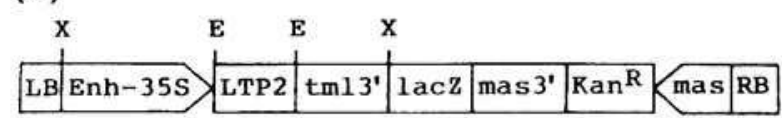

(b)

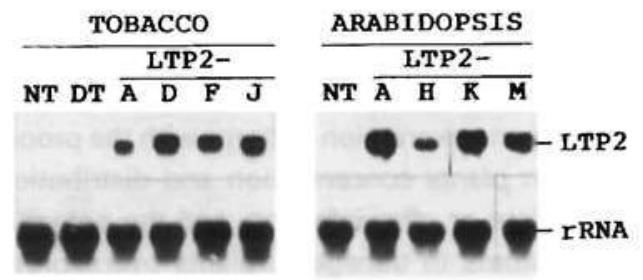

Figure 1. Transgenic expression of LTP2 from barley in tobacco and Arabidopsis.

(a) Schematic representation of T-DNA in plasmid pCIB200LTP2. LB, left border; Enh-35S, enhanced 35S promoter; LTP2, barley LTP2 CDNA; tmI3', $\mathrm{tm}^{\prime}$ gene $3^{\prime}$ untranslated sequence; lac $Z$, sequence of the $\beta$-galactosidase $\alpha$-fragment; mas3', mannopine synthase $3^{\prime}$ untranslated sequence; $\operatorname{Kan}^{R}$, neomycin phosphotransferase II gene conferring kanamycin resistance; mas, mannopine synthase promoter; RB, right border. The restriction sites for the endonucleases $X$ bal $(X)$ and $E$ coRI $(E)$ used for cloning are indicated. (b) Northern blot analysis ( $10 \mu \mathrm{g}$ of total RNA per lane) of non-transformed (NT) and transformed plants (LTP2-); plus a transformant with a partially deleted LTP2 CDNA (DT). Four independent homozygous lines of tobacco $(A, D, F, J)$ and Arabidopsis $(A, H, K, M)$ were tested. Filters were hybridized with a specific LTP2 probe. A $25 S$ rRNA probe was used as sample loading control.

\section{Results}

\section{Generation of LTP2 transgenic tobacco and Arabidopsis}

To evaluate the defense potential of LTPs, transgenic tobacco and Arabidopsis plants were obtained that expressed the LTP2 from barley under the control of a strong, constitutive promoter (Figure 1a). The nucleotide sequence encoding the signal peptide was included in the gene fusion to mediate export of the protein to the cell wall (Molina and Garcia-Olmedo, 1993). Four homozygous lines with high mRNA levels from each species were chosen for further study (Figure 1b). These lines showed no differences in their morphology and growth characteristics with respect to non-transformed plants. Concentrations of LTP2 in the leaves of the selected homozygous lines range from 3-10 $\mu \mathrm{mol} \mathrm{kg}^{-1}$, as estimated from Western blots (Figure 2a). In tobacco, plants transformed with a partially deleted LTP2 cDNA sequence, which lacked the polyadenylation signal and did not produce detectable mRNA or protein, were used as negative controls.

Tissue-print analysis of the transgenic plants showed that, as expected, the protein was evenly distributed accross leaf and stem sections (Figure 2b). This was in contrast with its location in barley, where it is preferentially distributed in the epidermis of exposed surfaces and in the vascular tissue (Molina and Garcia-Olmedo, 1993), as well as with the epidermal location of endogenous LTPs in (a)

\section{TOBACCO}

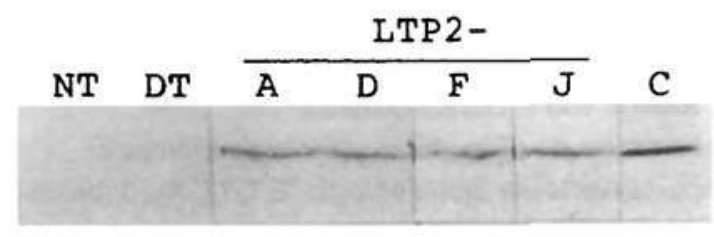

\section{ARABIDOPSIS}

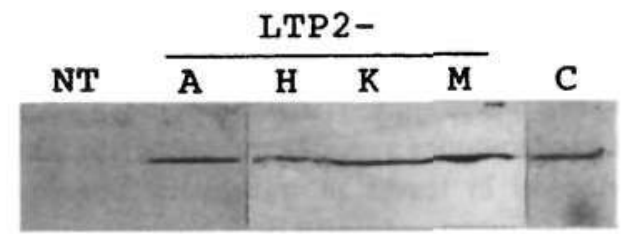

(b)

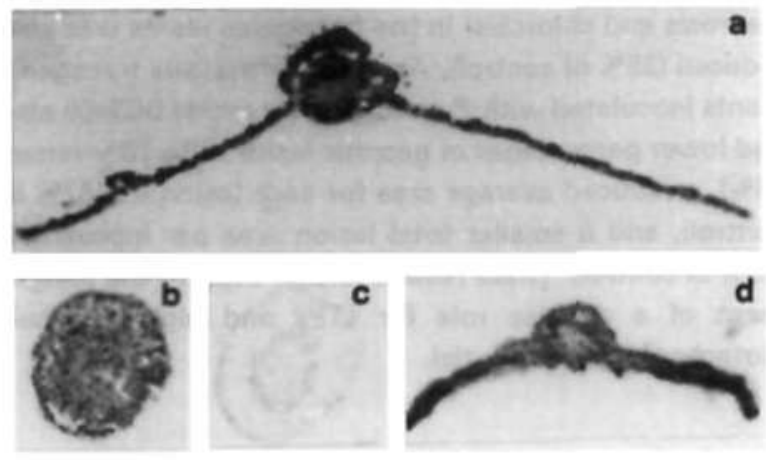

Figure 2. Analysis of LTP2 expression in transgenic plants using a polyclonal antibody.

(a) Western blot of protein extracts from tobacco and Arabidopsis. NT, non-transformed; DT, partially deleted LTP2 transformant; LTP2-, LTP2 transformed homozygous lines; C, purified LTP2 protein (150 $\mathrm{ng}$ ).

(b) Tissue-printing detection of LTP2 protein in tobacco and Arabidopsis. Transverse sections of tobacco leaf (a) and stem (b) from transformant, stem from non-transformed tobacco (c), and leaf from Arabidopsis transformant (d).

tobacco (Fleming et al., 1992) and Arabidopsis (Thoma et al., 1993).

\section{Evaluation of LTP2 transgenic tobacco}

The tobacco-pathogenic, LTP-sensitive bacterium Pseudomonas syringae pv. tabaci 153 was chosen to carry out detailed pathogenecity tests in tobacco as in initial tests it produced consistent symptoms in non-transformed tobacco cv. Xanthi, which could be accurately measured. These symptoms disappeared in a concentration-dependent manner when the purified barley LTP2 protein (Molina et al., 1993b) was simultaneously applied with the inoculum to the leaf surface of non-transformed tobacco (Figure 3a). 
(a)

0
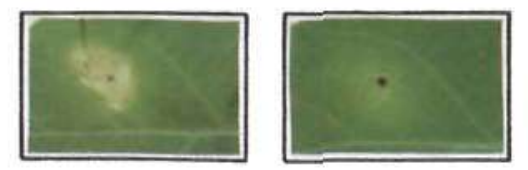

LTP2 $(\mu \mathrm{g})$

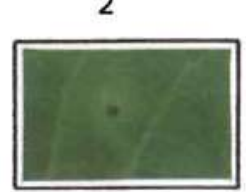

4

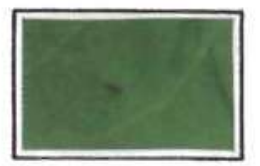

(b)

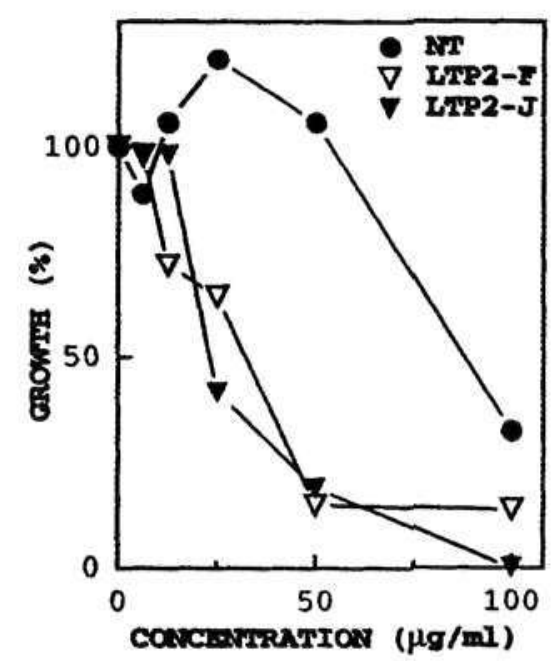

(c)

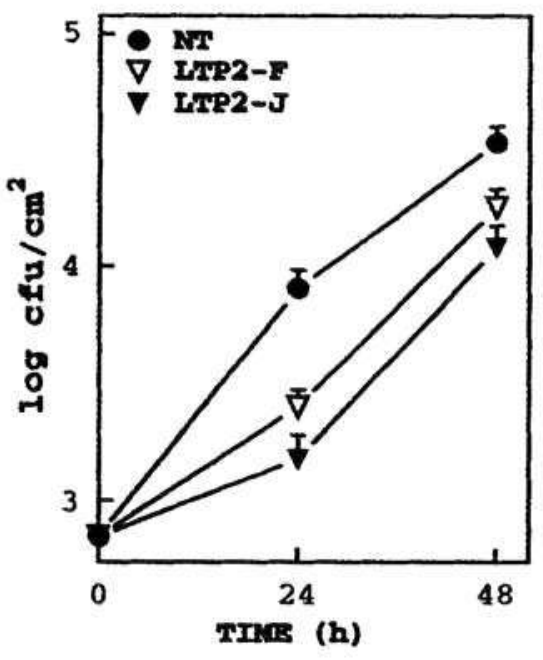

Figure 3. LTP2 effects on Pseudomonas syringae pv. tabaci 153.

(a) Effect of treatment of the tobacco surface with LTP2 on symptoms caused by the bacterium.

(b) In vitro inhibition of the bacteria by tobacco cell-wall protein extracts of non-transformed plants (NT) and LTP2 transformants (LTP2-) Concentrations of total cell-wall protein are given; LTP2 contents of extracts from trans formed leaves were estimated by Western blot as $10-12 \%$ of total protein in the extract. (c) Bacterial growth in leaves of non-transformed (NT) and transformed (LTP2-) tobacco. This experiment is one of three performed which gave similar results. Standard errors of the mean are represented by bars. Growth differences of the bacterium in the LTP2- ver sus the NT plants were significant $(P<0.05)$.
Cell-wall extracts from LTP2 transgenic plants, which were checked for LTP2 content by Western blot (not shown), inhibited bacterial growth in vitro at concentrations at which extracts from non-transformed tobacco had no effect (Figure $3 b$ ). Furthermore, growth of the bacterium on the leaves of transgenic plants was retarded with respect to that in non-transformed leaves (Figure 3c).

Plants from the four selected tobacco transformed homozygous lines were infiltrated with P. syringae pv. tabaci 153 and the percentage of inoculation points in which necrosis could be detected was recorded over a period of 12 days (Figure 4). In preliminary experiments, the inoculum was adjusted to produce detectable necrosis in about $80 \%$ of the inoculations performed on non-transformed tobacco under the described experimental conditions. The four transformants presented significantly lower percentages of necrotic lesions (17-38\%) compared with non-transformed tobacco control plants $(78 \%)$ and the average area of these necrotic lesions was also reduced $(61-81 \%$ of control). At the end of the experiment, the average total lesion area (necrosis plus chlorosis) per inoculation was measured and a reduction to $38 \%$ of non-transformed control values $(P<0.001)$ was again observed in the transformants (Figure 5).

\section{Evaluation of LTP2 transgenic Arabidopsis}

The protective effect of LTP2 was also investigated in transgenic Arabidopsis using the virulent, LTP2-sensitive bacterium $P$. syringae pv. tomato $\mathrm{DC} 3000$ and following the same criteria as for the tobacco/P. syringae pv. tabaci 153 experiments described above. The results, which are summarized in Figures 6 and 7, show clear decreases in symptoms in the LTP2 transgenic plants compared with the non-transformed controls: lower percentages of necrotic lesions $(22-38 \%$ versus $76 \%)$, reduced necrotic area per necrotic lesion (53-67\% of control), and smaller total (necrotic plus chlorotic) lesion area per inoculation $(43 \%$ of control; $P<0.001$ ).

\section{Discussion}

It has been shown that there are considerable differences in sensitivity to LTPs among different pathogenic bacterial and fungal species - or even among strains or isolates of the same species - and that differences in sensitivity towards LTP variants against a given pathogen are comparatively small (Molina and Garcia-OImedo, 1991; Molina et al., 1993b; Segura et al., 1993). The mechanism of action 

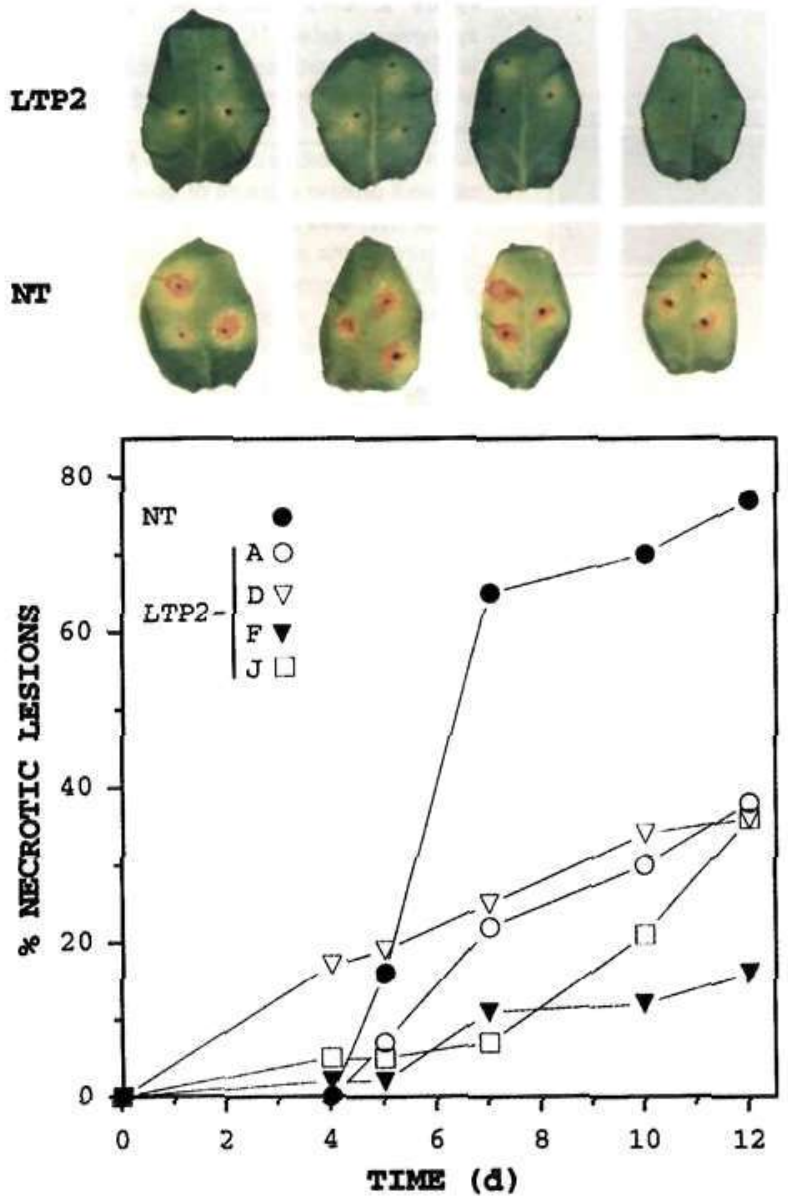

Figure 4. Chairenge or transgenic todacco piants witn r. syrıngae pv. taoacı 153. Representative lesions caused by the bacteria 12 days after inoculation in non-transformed (NT) and LTP2-transformed leaves (LTP2-) are shown. Percentages of necrotic lesions were scored at the times indicated. At least 42 inoculation points and 14 plants were treated for each transformant or control. This experiment is one of three performed which gave similar results.

of LTPS is not yet well understood, but it seems to be different from those of other plant defense proteins, such as thionins or defensins, as judged from the differences in activity spectra (Molina and García-Olmedo, 1994). Based on these observations, transgenic expression of an LTPcoding sequence under a strong, constitutive promoter should not essentially change the specificity of the LTP defense barrier already in existence in the recipient plant, but would reinforce and extend it by increasing basal LTP levels in epidermal regions and by leading to significant LTP accumulation in places with little or no endogenous LTPs. Tissue-print expression analysis of the transgenic plants and the increased antibiotic activity of their cell-wall protein extracts reported here indicate that this was the case. This pattern of expression would enhance resistance to pathogens by interfering with their penetration, propagation and movement inside the plant. In the case of bacteria used in this study, the pattern of transgenic expression
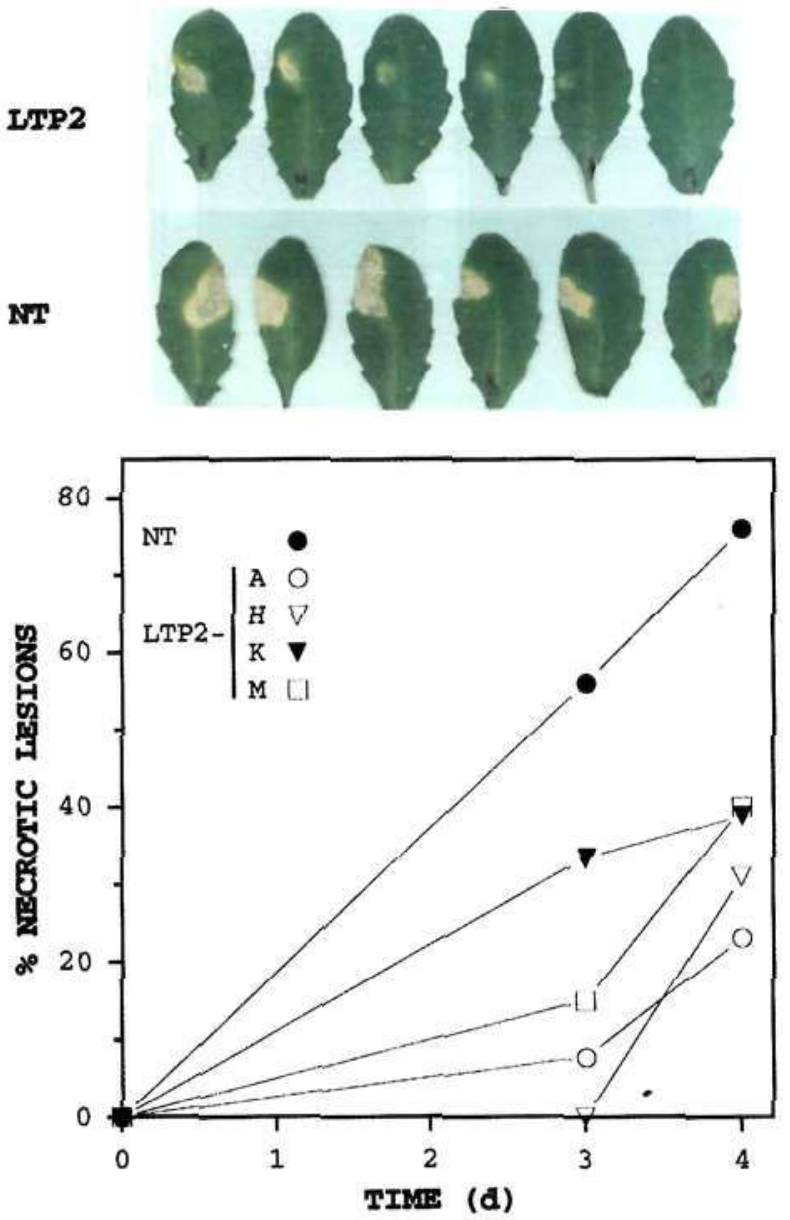

Figure 6. Challenge of transgenic Arabidopsis plants with P. syringae pv. tomato DC3000.

Representative lesions caused by the bacteria 4 days after inoculation in non-transformed plants (NT) and LTP2 transformants (LTP2-) are shown. Percentages of necrotic lesions were scored at the times indicated. At least 15 inoculation points and 15 plants were treated for each transformant or control. This experiment is one of three performed with similar resuits.

would not only interfere with growth on the leaf surface but aiso prevent progress through stomata and small lesions. The results of the analysis of bacterial growth showed that the propagation of bacteria on leaves of the transgenic plants was retarded with respect to that on nontransformed plants.

Evidence has been presented indicating that externally added, purified LTP2 is effective in preventing the symptoms caused by inoculation of the bacterial pathogen on the leaf surface. This does not exclude the possibility that correlation between in vitro and in planta LTP inhibitory properties might not be found for other pathogens because of possible differences in their growth characteristics in liquid media compared with plant tissues. Such differences have been shown, for example, in the case of thionins (Molina et al., 1993a).

The reductions of $P$. syringae symptoms caused by LTP2 


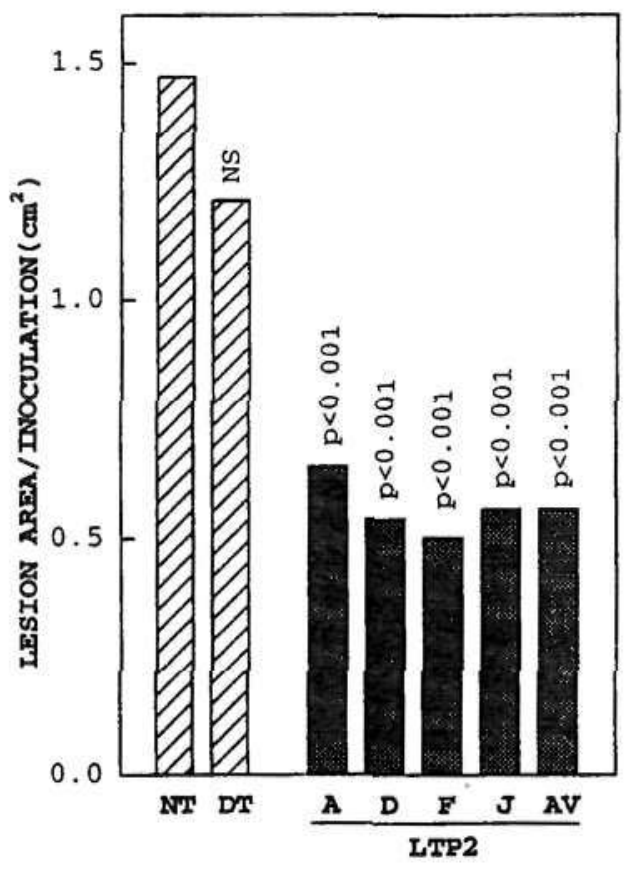

Figure 5. Total lesion area (chlorosis plus necrosis) per inoculation caused in tobacco plants by P. syringae pv. tabaci 153 in the experiment described in Figure 4.

Significance was calculated by the pairwise $t$ test. NT, non transformed DT, transformed with a partially-deleted LTP2 CDNA; $(A, D, F, J)$, independent transformants; AV, average for transformed plants.

overexpression in tobacco and Arabidopsis are similar and of the same order of those observed for other pathogens in transgenic plants overexpressing other plant antibiotic proteins (Alexander et al., 1993; Carmona et al., 1993; Jach et al., 1995; Lin et al., 1995; Liu et al., 1994; Logemman et al., 1992; Terras et al., 1995). This evidence further supports the assignment of a defensive role to LTPS and is in line with recent observations indicating that LTPsensitive mutants of $P$. solanacearum are avirulent (Titarenko, E., López-Solanilla, E., Garcia-Olmedo, F. and Rodriguez-Palenzuela, P., unpublished results). The role of LTPs as active components of both constitutive (Molina and García-Olmedo, 1993; Molina et al., 1993b; Segura et al., 1993) and inducible (García-Olmedo et al., 1995; Molina and Garcia-OImedo, 1993, 1994) defense barriers does not exclude the possibility that some or all of the members of this protein family might have other functions in response to various stresses (Hughes et al., 1992; Plant et al., 1991; Torres-Schumann et al., 1992), during development (Sterk et al., 1991; Tchang et al., 1988), or during the course of normal metabolism (Arondel and Kader, 1990; Yamada, 1992).

As recently reviewed (Lamb et al., 1992), strategies to engineer plants against pathogens are based on the manipulation of either (i) regulatory mechanisms (i.e. signal perception and transduction), (ii) multi-gene defense mechanisms (i.e. biosynthesis of phytoalexins), or

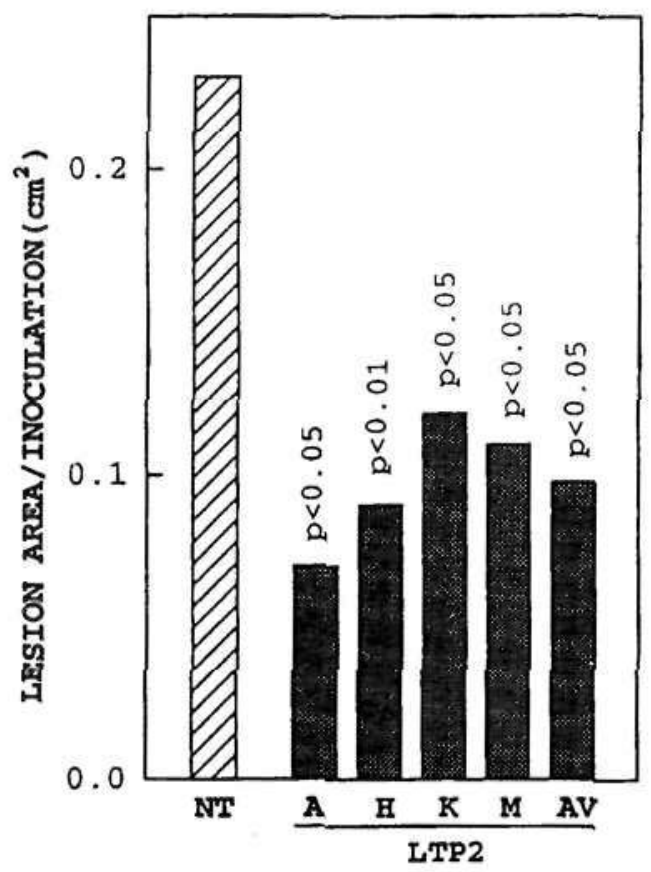

Figure 7. Total lesion area (necrotic plus chlorotic) per inoculation caused in Arabidopsis plants by P. syringae pv. tomato DC 3000 in the experiment described in Figure 6 . Significance was calculated by the pairwise $t$ test. NT, non transformed; (A, H, K, M), independent transformants; $A V$, average for transformed plants.

(iii) single-gene defense mechanisms. Our results demonstrate the potential use of Ltp genes in the context of the latter strategy. Other single proteins from plants as well as from non-plant sources (Lamb et al., 1992; Shah et al., 1995) have been shown to significantly enhance tolerance to pathogens. Gene combinations involving more than one of these proteins can be used in practice both to take advantage of synergistic effects and to create more polivalent barriers (Jach et al., 1995; Leah et al., 1991; Mauch et al., 1988; Terras et al., 1993; Zhu et al., 1994). In this context, it should be noted that synergism of LTPs with thionins has been demonstrated in vitro (Molina et al., 1993b).

\section{Experimental procedures}

\section{Transgenic plants}

A previously described LTP2 CDNA clone from barley containing the LTP2 signal peptide and mature protein-coding regions (Molina and Garcia-Olmedo, 1993) was subcloned into the EcoRI site of pCGN1716 (Comai et al., 1990) between the enhanced 35S promoter and the $t \mathrm{~m} / \mathrm{3}^{\prime}$ terminator (Figure 1). The cassette containing the cDNA in a sense orientation was then subcloned into the $X$ bal site of $\mathrm{pClB200}$, a binary vector containing the neomycin phosphotransferase II gene that confers kanamycin resistance, resulting in plasmid pCIB200LTP2. A gene construction including a $3^{\prime}$ partially deleted LTP2 cDNA clone was generated in a similar manner. The plasmids were transformed into Agrobacterium tumefaciens strain ClB542 (Hood et al., 1996) according to the 
procedure of Wen-jun and Forde (1989). Leaf disks of Nicotiana tabacum cv. Xanthi were inoculated with the $A$. tumefaciens strains and selected on kanamycin (Horsch et al., 1985). A single shoot ( $T_{1}$ generation) was regenerated from each leaf disk and grown in soil until seed set. Seeds $\left(T_{2}\right.$ generation) resulting from self-pollination of the regenerated transformants were scored for antibiotic resistance on MS medium (Sigma, St Louis, MO) containing $100 \mathrm{mg} \mathrm{r}^{1}$ of kanamycin. Those giving a 3:1 tresistant: susceptible) segregation for the kanamycin marker were checked for expression by the Northern and Western blot techniques. Homozygous lines were identified by screening ten kanamycinresistant $T_{2}$ progeny from each independent transformant $\left\langle T_{3}\right.$ generation) for non-segregation of the marker. Roots of 10-14day-old $A$. thaliana ecotype $D i j o n ~ O$ plants were inoculated with A. tumefaciens and selected on kanamycin (25 $\left.\mathrm{mg} \mathrm{l}^{-1}\right)$ as described by Huang and $\mathrm{Ma}$, (1992). $\mathrm{T}_{3}$ homozvgous lines were selected as above.

\section{Analysis of RNA and protein}

Total RNA (10 $\mu g$ ) was extracted from leaves of tobacco or Arabidopsis, subjected to electrophoresis on $1.5 \%$ formaldehyde/ agarose gels, blotted to Hybond $\mathrm{N}$ membranes (Amersham, UK) and hybridized at $65^{\circ} \mathrm{C}$ with a specific barley $L T P 2$ probe as previously described (Molina and Garcia-Olmedo, 1993). Proteins were extracted from leaves ( $150 \mathrm{mg}$ fresh weight) of tobacco or Arabidopsis with three volumes of sample buffer, subjected to electrophoresis on $12 \%$ SDS-polyacrylamide gels (Laemmli, 1970). and transfered to polyvinilidene difluoride membranes (ImmobiIon, Millipore, Bedford, MA) according to Towbin et al. (1979). Western blots and tissue prints were carried out as previously described (Molina and Garcia-Olmedo, 1993).

\section{Tests with pathogens}

Transformants and non-transformed controls were grown in sterile soil in multi-well plastic containers that were kept in a growth chamber (Heraeus, Balingen, Germanyl at $75 \%$ relative humidity, $25^{\circ} \mathrm{C}, 16 \mathrm{~h}$ (day) and $65 \%$ relative humidity, $23^{\circ} \mathrm{C}, 8 \mathrm{~h}$ (night) for tobacco, and at $75 \%$ relative humidity, $23^{\circ} \mathrm{C}, 12 \mathrm{~h}$ (day) and $65 \%$ relative humidity, $21^{\circ} \mathrm{C}, 12 \mathrm{~h}$ (night) for Arabidopsis. Tobacco inoculation with $P$. syringae pv. tabaci 153 (15 $\mu 1,2 \times 10^{5}$ c.f.u. $\mathrm{ml}^{-1}$ in $10 \mathrm{mM} \mathrm{MgCl}$ \} was carried out by infiltration into the abaxial side of intact leaves from 12-week-old plants with a plastic syringe without a needle, and inoculation points were labeled by ink marks on the upper surface (Figure 4). Five-week-old Arabidopsis plants were similarly inoculated with the bacteria $P$. syringae pv. tomato DC $3000\left(15 \mu \mathrm{l} 5 \times 10^{5}\right.$ c.f.u. $\mathrm{ml}^{-1}$ in $10 \mathrm{mM}$ $\mathrm{MgCl}_{2}$ ). After inoculation, plants were kept at $85 \%$ (day) and $75 \%$ (night) relative humidity.

Barley LTP2 protein was purified as previously described (Molina et $\left.a_{1}, 1993 \mathrm{~b}\right)$ and co-infiltrated with $P$, syringae pv. tabaci $(200$ c.f.u. per inoculation) in the abaxial side of the leaves of 12-weekold non-transformed tobacco, using a plastic syringe without a needle; symptoms were evaluated 12 days after infiltration. Cellwall extracts containing LTPs were obtained from tobacco leaves, and used for in vitro inhibition tests as described by Molina ef al. (1993b). Bacterial growth in leaves was monitored by harvesting and homogenizing at each stage three leaves which had been previously infiltred with $750 \mathrm{c.f.u}$. of the bacterium. Appropriate 10-fold dilutions were plated in nutrient broth agar (Difco, Detroit, Ml) containing the selection antibiotic rifampycin $\left(100 \mu \mathrm{g} \mathrm{ml}^{-1}\right)$ and colonies were counted.

\section{Acknowledgments}

The collaboration of D. Negrotto and S. Dincher /Ciba-Geigy Corp., Research Triangle Park, NC, USA) with the transformation and selection of transgenic plants, and the technical assistance of $L$. Lamoneda and J. Garcia are gratefully acknowledged. This work was financed by the Dirección General de Investigación Cientifica y Técnica (Spain), grant PB92/0325.

\section{References}

Alexander, D., Goodman, R.M., Gut-Rella, M. et al. (1993) Increased tolerance to two oomycete pathogens in transgenic tobacco expressing pathogenesis-reiated protein 1a. Proc. Nati Acad. Sci. USA, 99, 7327-7331.

Arondel, V. and Kader, J.-C. (1990) Lipid transfer proteins in plants. Experientia, 46, 579-585.

Bohlmann, H., Clausen, S., Behnke, S., Giese, H., Hiller, C., Reimann-Philipp, U., Schrader, G., Barkholt, V. and Apel, K. (1988) Leaf-specific thionins of barley - a novel class of cell wall proteins toxic to plant-pathogenic fungi and possibly involved in the defence mechanism of plants. EMBO J. 7, 1559-1565.

Bowles, D.J. (1990) Defense-related proteins in higher plants. Annu. Rev. Biochem. 59, 873-909.

Broglie, K., Chet, I., Holliday, M., Cressman, R., Biddle, P.. Knowiton, S., Mauvais, C.J. and Broglie, R. (1991) Transgenic plants with enhanced resistance to the fungal pathogen Rhizoctonia solani. Science, 254, 1194-1197.

Carmona, M.J., Molina, A., Fernández, J.A., López-Fando, J.J. and Garcia-Olmedo, F. (1993) Expression of the $\alpha$-thionin gene from barley in tobacco confers enhanced resistance to bacterial pathogens. Plant J. 3, 457-462.

Comai, L., Moran, P. and Maslyar, D. (1990) Novel and useful properties of a chimeric plant promoter combining CaMV $35 S$ and MAS elements. Plant Mol. Biol. 15, 373-381.

Fernández de Caleys, R., González-Pascual, B., Garcia-Olmedo, F. and Carbonero, P. (1972) Susceptibility of phytopathogenic bacteria to wheat purothionins in vitro. Appl. Microbiol. 23, 998-1000.

Fleming, A.W., Mandel, T., Hofmann, S., Sterk, P., de Vries, S.C. and Kuhlemeier, C. \{1992) Expression pattern of a tobacco lipid transfer protein gene within the shoot apex. Plant J. 2, 855-862.

García-Olmedo, F., Carmona M.J., López-Fando, J.J., Fernández, J.A., Castagnaro, A., Molina, A., Hernández-Lucas, C. and Carbonero, P. (1992) Characterization and analysis of thionin genes. In Genes involved in Plant Defense (Boller, T. and Meins,

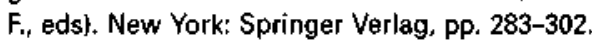

Garcia-Olmedo, F., Molina, A., Segura, A. and Moreno, M. (1995) The defensive role of nonspecific tipid-transfer proteins in plants. Trends Microbiol. 3, 72-74.

Hejgaard, S., Jacobsen, S. and Svendsen, I. (1991) Two antifungal thaumatin-like proteins from barley grain. FEBS Lett. 291, 127-131.

Hendriks, T., Meijer, E.A., Thoma, S., Kader, J.C. and de Vries, S.C. (1994) The carrot extracellular lipid transfer protein EP2: quantitative aspects with respect to its putative role in cutin synthesis. In Plant Molecular Biology (Coruzzi, G. and Puigdomenech, P., eds). Heidelberg: Springer Verlag, pp. 85-94.

Hood, E.E., Helmer, G.L., Fraley, R.T. and Chilton, M.-D. (1986) The hypervirulence of Agrobacterium tumefaciens A281 is encoded in a region of pTiBo542 outside of T-DNA. J. Bacteriol. 168, 1291-1301.

Horsch, R.B., Fry, J.E., Hoffimann, N.L, Eichholtz, D., Rogers, 
S.G. and Fraley, R.T. (1985) A simple and general method for transferring genes into plants. Science, 227, 1229-1231.

Huang, H. and Ma, H. (1992) An improved procedure for transforming Arabidopsis thaliana (Landsberg erectal root explant. Plant Mol, Biol. Rep. 10, 372-383.

Hughes, M.A., Dunn, M.A., Pearce, R.S., White, A.J. and Zhang, L. (1992) An abscisic-acid-responsive, low temperature barley gene has homology with a maize phospholipid transfer protein. Plant Cell Environ. 15, 861-865.

Jach, G., Görnhardt, B., Mundy, J., Logemman, J., Pinsdorf, E., Leah, R., Schell, J. and Maas, C. (1995) Enhanced quantitative resistance against fungal disease by combinatorial expression of different barley antifungal proteins in transgenic tobacco. Plant J. 8, 97-109.

Laemmll, U.K. (1970) Cleavage of structural proteins dusing the assembly of the head bacteriophage T4. Nature, 227, 680-685.

Lamb, C.J., Ryals, J., Ward, E.R. and Dixon, R.A. (1992) Emerging strategies for enhancing crop resistance to microbial pathogens. Biotechnology, 10, 1436-1445.

Leah, R., Tornmerup, H., Svendsen, 1. and Mundy, J. (1991) Biochemical and molecular characterization of three barley seed proteins with antifungal properties. J. Biol. Chem. 266, 1464-1473

Lin, W., Anuratha, C.S., Datta, K., Potrykus, I., Muthukrishnan, S and Datta, S.K. (1995) Genetic engineering of rice for resistance to sheath blight. Biotechnology, 13, 686-691.

Liu, D., Raghothama, K.G., Hasegawa, P.M. and Bressan, R.Y (1994) Osmotin overexpression in potato delays development of disease symptoms. Proc. Natl Acad. Sci. USA, 91, 1888-1892.

Logemman, J., Jach, G., Tommerup, H., Mundy, J. and Schell, J. (1992) Expression of a barley ribosome-inactivating protein leads to increased fungal protection in transgenic tobacco plants. Biotechnology, 10, 305-308.

Mauch, F., Mauch-Mani, B. and Boller, T. (1988) Antifungal hydrolases in pea tissue. II. Inhibition of fungal growth by combinations of chitinases and B-1,3-glucanases. Plant Physiol. 88, 936-942.

Molina, A. and Garcia-OImedo, F. (1991\} Novel Antipathogenic Peptides and Compositions Containing the Same. Patent application P9101258 (24.05.91) PCT/EP92/01130. US Patent 5446127 (8.29.1995).

Molina, A. and Garcia-Olmedo, F. (1993) Developmental and pathogen-induced expression of three barley genes encoding lipid transfer proteins. Plant J. 4, 983-991.

Molina, A., Ahl-Goy, P., Fraile, A., Sánchez-Monge, R. and GarciaOlmodo, F. (1993a) Inhibition of bacterial and fungal plant pathogens by thionins of types I and II. Plant Sci. 92, 169-177.

Molina, A. and García-Olmedo, F. (1994) Expression of genes encoding thionins and lipid-transfer proteins. A combinatorial model for the responses of defense genes to pathogens. In Plant Molecular Biology (Coruzzi, G. and Puigdomènech, P., eds]. Heidelberg: Springer Verlag, pp. 235-244.

Molina, A., Segura, A. and Garcia-Olmedo, F. (1993b) Lipid transfer proteins (nSLTPs) from barley and maize leaves are potent inhibitors of bacterial and fungal plant pathogens. FEBS Lett. 316, 119-122.

Moreno, M., Segura, A. and Garcia-Olmedo, F. (1994) Pseudothionin-St1, a potato peptide active against potato pathogens. Eur. J. Biochem. 223, 135-139.

Mundy, J. and Rogers, J.C. (1986) Selective expression of a probable amylase/protease inhibitor in barley aleurone cells: comparison to the barley amylase/subtilisin inhibitor. Planta, 169, 51-63.
Plant A.L, Cohen, A., Moses, M.S. and Bray, E.A. (1991) Nucleotide sequence and spatial expression pattern of a drought- and abscisic acid-inducible gene of tomato. Plant Physiol. 97, 900906.

Pyoe, J., Yu, H. and Kolattukudy, P.E, (1994) Identification of a lipid transfer protein as the major protein in the surface wax of broccoli (Brassica oleracea) leaves. Arch. Biochem. Biophys. 311, 460-468.

Segura, A., Moreno, M. and Garcia-Olmedo, F. (1993) Purification and antipathogenic activity of lipid transfer proteins (LTPs) from the leaves of Arabidopsis and spinach. FEBS Lett. 332, 243-246.

Shah, D.M., Rommens C.M.T. and Beachy, R.N. (1995) Resistance to diseases and insects in transgenic plants: progress and applications to agriculture. Trends Biotechnol. 13, 362-369.

Sterk, P., Booij, H., Schellekens, G.A., Van Kammen, A. and de Vries, S.C. (1991) Cell-specific expression of the carrot EP2 lipid transfer protein gene. Plant Cell, 3, 907-921.

Tchang. F., This, P., Stiefel, V. et al. (1988) Phospholipid transfer protein: full-length CDNA and amino acid sequence in maize. $J$. Biol. Chem. 263, 16 849-16 855.

Terras, F.R.G., Goderis, I.J., Van Leuven, F., Vanderteyden, J., Cammue, B.P.A. and Broekaert, W.F. (1992a) in vitro antifungal activity of a radish (Raphanus sativa L.) seed protein homologous to nonspecific lipid transfer proteins. Plant Physiol. 100, 1055-1058.

Terras, F.R.G., Schoofs, H.M.E., De Bolle, M.F.C., Van Leuven, F. Rees, S.B., Vanderleyden, J., Cammue, B.P.A. and Broekaert, W.F. (1992b) Analysis of two novel classes of antifungal proteins from radish (Raphanus sativus L.) seeds. J. Biol. Chem. 267 $15301-15309$.

Terras, F.R.G., Schoofs, H.M.E., Thevissen, K., Osborn, R.W. Vanderlyden, J., Cammue, B.P.A. and Broekaert, W.F. (1993) Synergistic enhancement of the antifungal activity of wheat and barley thionins by radish and oilseed rape $2 S$ albumins and by barley trypsin inhibitors. Plant Physiol. 103, 1311-1319.

Terras, F.R.G., Eggermont, K., Kovaleva, V. et al. (1995) Small cysteine-rich antifungal proteins from radish: their role in host defense. Plant Cell, 7, 573-588.

Thoma, S., Kaneko, Y. and Somerville, C. (1993) A non-specific lipid transfer protein from Arabidopsis is a cell wall protein. Plant J. 3, 427-436.

Torres-Schumann, S., Godoy, J.A. and Pintor-Toro, J.A. (1992) A probable lipid transfer protein gene is induced by $\mathrm{NaCl}$ in stems of tomato plants. Plant Mol. Biol. 18, 749-757.

Towbin, H., Staehelin, T. and Gordon, J. (1979) Electrophoretic transfer of proteins from polyacrylamide gels to nitrocellulose sheets: procedure and some practical applications. Proc. Nat' Acad. Sci. USA, 76, 4350-4354.

Vigers, A.J., Roberts, W.K. and Selitrennikoff, C.P. (1991) A new family of plant antifungal proteins. Mol. Plant-Microbe interact. 4, 315-323.

Wen-jun, S. and Forde, B.G. (1989) Efficient transformation of Agrobacterium spp. by high voltage electroporation. Nucl. Acids Res. 17, 8385.

Woloshuk, C.P., Meulenhoff, J.S., Sela-Buurlage, M., van den Elzen, P.J.M. and Cornelissen, B.J.C. (1991) Pathogen-induced proteins with inhibitory activity toward Phytophtora infestans. Plant Cell, 3, 619-628.

Yamada, M. (1992) Lipid transfer proteins in plants and microorganisms. Plant Cell Physiol. 33, 1-6.

Zhu, Q. Maher, E.A., Masoud, S., Dixon, R.A. and Lamb, C.J. (1994) Enhanced protection against fungal attack by constitutive co-expression of chitinase and glucanase genes in transgenic tobacco. Biotechnology, 12, 807-812. 